\title{
Research on the Development of the Advantage and Characteristic Agricultural Industry Supported by Finance-Taking Dazhou as an Example
}

\author{
Guangming Xiong \\ School of Finance and Economics Management, Sichuan University of Arts and Science, Dazhou, China \\ Email: xiongguangming0728@163.com
}

How to cite this paper: Xiong, G.M. (2021) Research on the Development of the Advantage and Characteristic Agricultural Industry Supported by Finance-Taking Dazhou as an Example. Open Access Library Journal, 8: e7919.

https://doi.org/10.4236/oalib.1107919

Received: September 1, 2021

Accepted: September 14, 2021

Published: September 17, 2021

Copyright $\odot 2021$ by author(s) and Open Access Library Inc.

This work is licensed under the Creative Commons Attribution International License (CC BY 4.0).

http://creativecommons.org/licenses/by/4.0/

\begin{abstract}
The revitalization of rural areas is primarily based on the prosperity of the industry, and the key to the prosperity of the industry lies in the cultivation of a new type of agricultural business entity. By studying the current situation of agricultural industry development and the main problems existing in the development of agricultural industrialization in Dazhou, this paper illustrates the financing difficulties of the main body of agricultural industrialization development, puts forward policy suggestions from the perspective of financial support including cultivating and expanding new agricultural business subjects, supporting financial innovation, strengthening the construction of financial infrastructure and optimizing assessment methods, and aims to improve the availability, coverage and convenience of the development of the characteristic agricultural industry with financial service advantages.
\end{abstract}

\section{Subject Areas}

Finance

\section{Keywords}

Finance, New Agricultural Business Entities, Industrialization

\section{Introduction}

The "Implementation Plan for the Construction of Agricultural Modernization Demonstration Zones" clearly states that it is necessary to comprehensively consider factors such as regional differences and development foundations, to build 
a batch of modernized agricultural demonstration areas. One of them is the modernization demonstration zone of advantageous characteristic industries based on park and integration. This type focuses on industrial characteristics and is established in areas with high industrial concentration, distinctive characteristics and prominent comparative advantages. Dazhou is a city with a large population. The terrain is dominated by hills. The comprehensive conditions such as climate and economic foundation make its agriculture suitable for the development road of advantageous characteristic industry modernization dominated by park and integration. At present, some scholars have conducted researches on the industrialization of agriculture and rural finance, but researches on financial support for the modernization of advantageous and characteristic industries, which are mainly based on parks and integration, are not in-depth. Therefore, the study of financial support for the development of industrial parks and fusion-oriented advantageous characteristic industries not only has significance in theory, but also in practice.

\section{Development Status of Agricultural Industry in Dazhou}

Dazhou is a major agricultural city in Sichuan Province, with an effective irrigated area of 1978.8 square kilometers of cultivated land. In 2020, the total grain output was 3.194 million tons, ranking first in the province; the total output of rapeseed was 314,800 tons, ranking third in the province. The annual production of live pigs reaches 3.702 million heads, the output of main livestock and poultry meat is 436,600 tons, and the total output of aquatic products is 104,700 tons.

The agricultural park is developing rapidly. Dazhou has achieved remarkable results in the construction of modern agricultural parks, including 5 provincial-star modern agricultural parks, 19 municipal parks and 56 county-level parks. A total of 311.3 square kilometers of characteristic industrial bases focusing on Anren pomelo, ginkgo, olive, Toona sinensis, black plum and green pepper have been built. The main characteristic industry base is 311.3 square kilometers. Dazhou has created 1 advantageous area for agricultural products with Chinese characteristics, 6 provincial-level; 13 provincial and ministerial-level livestock and poultry standardization demonstration farms, and 6 national aquatic healthy breeding demonstration farms. New business entities continue to grow. Dazhou has cultivated 3 national-level leading enterprises, 38 provincial-level leading enterprises, and 162 municipal-level leading enterprises, and cultivated more than 15,000 new-type professional farmers.

The level of agricultural technology and material technology equipment has been greatly improved. The application rate of information technology such as the Internet of Things in agriculture reaches 35\%; the coverage rate of good varieties of crops is higher than $97 \%$. Dazhou established the country's first municipal-level crop seed testing regional sub-center, built 3 provincial-level livestock and poultry resource protection areas, and 2 livestock and poultry core breeding farms. In 2020, the total power of agricultural machinery in Dazhou reached 
2.8427 million KW, and the comprehensive mechanization rate of the cultivation and harvest of major crops reach $60.72 \%$; the static storage capacity of agricultural cold chain logistics facilities reach 131,000 tons.

Integrated development of agricultural industry in Dazhou City: build 4 agricultural product processing concentrated areas, 6 agricultural product processing parks, and cultivate 5 agricultural industrialization consortia. The agricultural brand building has achieved remarkable results. It has successfully registered the regional public brand of "Bashan Food Hui" agricultural products, cultivated 4 well-known trademarks in China, 21 national ecological origin protection products, and 10 high-quality agricultural products brands in Sichuan Province. Dazhou has integrated agriculture and tourism development, and built 3 national-level beautiful leisure villages, 7 provincial leisure agriculture theme parks and 15 provincial demonstration leisure farms; it has been selected into 1 National Rural Tourism key village, 4 provincial-level villages and 7 "the most beautiful ancient town and ancient village in Sichuan" [1].

\section{The Main Problems in the Development of Agricultural Industrialization in Dazhou}

Agricultural infrastructure needs to be improved, new agricultural management organizations are relatively few, and industrial integration is insufficient. First, the agricultural infrastructure is relatively weak. The effective irrigated area only accounts for $39.29 \%$ of the arable land. A total of 2340 square kilometers of highstandard farmland has been built, but the proportion of high-standard farmland is relatively low. Second, the number of new agricultural management organizations in Dazhou is relatively small, and the scale is insufficient. In particular, the number of leading enterprises at the national and provincial levels is small, and many regions still traditional decentralized operations, with low product commercialization rates. Third, the degree of integration with the secondary and tertiary industries is not deep, the industrial chain is short, and the added value is not high.

Modern agricultural parks are not strong. The construction of modern agricultural parks can lead the high-quality development of agriculture and gather elements such as policies, funds, and talents. The number of existing agricultural parks in Dazhou is small and the strength is relatively weak. First, agricultural infrastructure is imperfect and the large amount of early investment in the park has discouraged many investors. Second, the existing land system has increased the construction cost of modern agricultural parks. The land per household is small and the negotiation cost in land transfer is high. Third, there are more migrant workers in rural areas, which bring inconvenience to land transfer. At the same time, there are fewer young and middle-aged laborers, which is not conducive to the construction of modern agricultural parks.

The application of science and technology is insufficient, and the quality, efficiency and competitiveness of the industry are still low. The level of agricultural 
industrialization is not high. The agricultural products are mainly primary products, with little intensive processing, lack of high-end and high-quality products, and little brand influence. The characteristic industries are many and complex, the layout is scattered, and the level of standardization and intensification is not high. Agricultural science and technology innovation is weak, high-tech talents are lacking, R\&D results are insufficiently transformed and used, the seed industry started late, the quality of farmers needs to be improved, and the overall core competitiveness is not strong. Modern agricultural equipment lags behind the needs of industrial development, and the mechanization rate needs to be improved.

The financing ability of new agricultural business entities is weak. Compared with traditional farmers, the new agricultural business entities have a larger scale of operation, more investment in assets, and greater demand for funds. Agriculture is cyclical, and most of the capital investment is difficult to form mortgaged assets, and it is difficult to realize some fixed assets. Compared with the secondary and tertiary industries, agriculture is greatly affected by natural factors such as climate, has a long operating cycle, "low grain price hurt farmers" from time to time, and agricultural profit margins are low. The capital accumulation of some new agricultural business entities is insufficient, and the risk mitigation and compensation capabilities of loans are weak.

\section{The Financing Dilemma of the Main Body of Agricultural Industrialization Development}

The financing dilemma of the main body of agricultural industrialization development is mainly manifested in the financing dilemma of the new agricultural business main body.

\subsection{The Credit Awareness of New Agricultural Business Entities Needs to Be Improved}

Some groups believe that there is no credit default or criminal behavior in the past, so credit is good. But from a financial point of view, in addition to the absence of bad credit information, the borrower's assets, capital flow, credit transactions, repayment ability, mortgage assets and other matters must also be considered. Dazhou's new agricultural business entities have relatively small business scale, low degree of market organization, low level of informatization, and few credit transactions. At the same time, there is information asymmetry between financial institutions and agricultural subjects [2]. In addition, rural private lending is more common, and the corresponding transactions are not included in the credit report. Financial institutions usually grant a certain loan line based on the borrower's credit, and if other financial institutions have already granted credit, the line is deducted. However, it is difficult for financial institutions such as banks to grasp the operating scale, operating conditions, and assets and liabilities of new agricultural operating entities [3]. 


\subsection{The Operation and Management of the New Agricultural Business Entity Needs to Be Improved}

Some new agricultural business entities have small business scales, irregular management, and lack of talents with financial risk management capabilities. Financial situation is an important basis for financial institutions to understand borrowers and can effectively reduce information asymmetry. The financial systems of some new agricultural business entities are not standardized. They only record some running accounts, record more or less, and have not formed financial statements that can truly reflect the financial situation. Daily transactions and credit information are not online or lack of records, and relatively standardized capital flow information has not been formed. Some new agricultural business entities have transaction information on the Internet, but the transactions are scattered and difficult for banks to grasp. The financing ability of agricultural business entities is weak and lacks the use of financial tools. The cost of financing is relatively high. According to the principle of marketization, risks and benefits are matched. The cost of financing depends on the credit ability of market entities, and is also related to the concept and credit culture of financial institutions.

\subsection{The Service Quality of Financial Institutions Needs to Be Improved}

The rural financial system is imperfect. New agricultural business entities have large-scale and long-term credit demand, and the existing financial products are poorly matched with the development of the agricultural industry. The loan qualifications of new agricultural financial entities do not match the bank credit conditions, such as irregular operation and management, weak ability to resist risks, and fewer assets that are effectively mortgaged. Financial institutions need to balance income, risk and liquidity. Compared with non-agricultural loans, agricultural loans are usually riskier, and bank funds often flow out of rural areas. As a result, rural funds are in short supply, and borrowing rates are higher. Information asymmetry is an important factor that causes farmers' financing difficulties, and an effective solution is to "sending signal." The credit information of rural households is relatively scattered and lacks "formal" records, which makes the credit evaluation of rural households by financial institutions low. The lack of financial risk management capabilities of rural households and the difficulty of financial institutions to grasp the information on mutual assistance in rural households' private capital lending will lead to information asymmetry between the supply and demand of rural finance. Individual or corporate account opening banks and main transaction flows are different from those of lending banks, resulting in incomplete information and affecting credit extension.

\subsection{Insufficient Innovation Capabilities of Agricultural Financial Institutions}

The current network layout and bank structure of agricultural-related financial institutions are not conducive to rural financial support for agriculture, and fi- 
nancial innovation capabilities are relatively weak. In economically underdeveloped areas, after state-owned commercial banks were restructured and listed, with the exception of the Agricultural Bank which kept business outlets in large townships, other state-owned banks almost completely withdrew from the township market. The banks that have opened business outlets in towns and villages mainly include Agricultural Bank, Rural Commercial Bank, Postal Savings Bank, and a small number of rural banks. In prefecture-level cities and counties, there are also city commercial banks in various regions that provide services for "agriculture, rural areas and farmers". Financial institutions outside banks are mainly small loan companies and guarantee companies, while securities and insurance institutions are relatively absent. Agricultural commercial banks have insufficient innovation capabilities, and the product structure of agricultural banks is relatively simple, mainly for deposits, loans and settlement businesses. Among them, credit is an important product of rural financial support for agriculture, and relevant banks have not yet been able to explore solutions that can be widely promoted in terms of credit evaluation and risk control. In terms of POS machine business, the township penetration rate is low. The collection mainly relies on WeChat, Alipay and cash. There are few credit card swiping scenarios. The stateowned banks other than Agricultural Bank lack branches in towns and towns, and the cost of marketing, installation and management of POS is relatively high. Abandon the promotion of POS business in towns and villages. Villages, towns and rural communities have low acceptance of mobile banking, and merchants also face problems such as inconvenient bank card settlement.

\section{Policy Recommendations}

\subsection{Cultivating and Strengthening New Agricultural Business Entities}

The poor quality of agricultural industry development in Dazhou, and the lack of a strong new agricultural business entity is an important reason for the difficulty in financing. New agricultural business entities are the key to the development of rural industries. Cultivating and growing new agricultural business entities is not only conducive to driving the development of the agricultural industry, opening the "gate" of financial support to agriculture, and also helping to increase farmers' income. The cultivation of new agricultural business entities and modern agricultural industries usually takes a long time. The cultivation of a new type of agricultural business entity requires multiple efforts. It requires the government to help solve infrastructure and institutional issues, as well as the continuous infusion of financial resources, and the optimization of the agricultural business environment by increasing credit investment in agricultural infrastructure. Improve the operation and management capabilities of the new agricultural business entities, and help them to update their technologies and introduce talents. Promote the construction of the rural financial information system, continuously standardize the financial system of the new agricultural business 
entities, reduce the information asymmetry between the banks and the new agricultural business entities, and at the same time help them regulate their operations. Financial personnel serving in rural areas should understand not only in finance, but also in agriculture and management, and reduce information asymmetry through early intervention. Strengthen the capital reserve of new agricultural business entities and enhance development capabilities. Government departments should organize financial talents to train and guide new agricultural business entities, assist them in their standardized operations, improve the use of modern financial tools by new agricultural business entities, and strengthen financial consumer protection. Promote the reform of the agricultural supply side, guide farmers to operate on an appropriate scale, promote land circulation, and develop characteristic agriculture. At the same time, the market-oriented transformation of the agricultural industry will promote the development of agricultural organization, branding, and Internet.

\subsection{Improve Financial Innovation and Service Capabilities}

The existing credit system cannot solve the problem of loan difficulties for some new agricultural business entities. Credit demand varies from region to region, and the design authority of credit products is usually reserved at the bank's head office or provincial branch, causing product design and actual demand to be easily disconnected. In the marketing process, the bank's basic branches respond to financial products based on the borrower's credit conditions, rather than designing financial products based on the borrower's needs. Only through financial innovation and exerting efforts from both ends, one is to make the "hard conditions" of the new agricultural business entity meet the bank's credit requirements, and the other is to innovate financial products that meet the financial needs, can the financing difficulties of the new agricultural business entity be resolved and the Financing costs be reduced. Promote diversified financing of agricultural-related enterprises, and give priority to supporting agricultural-related enterprises in issuing bonds and listing financing.

The financial needs of new agricultural business entities are diversified. Financial institutions should continue to enrich financial products, including credit, wealth management, settlement, insurance, futures, etc. Reshape credit and cultural structures, and improve financing services. Guide the integration and development of various technology platforms with traditional financial institutions, support local corporate banks to build "open banks", and support other agricultural banks to give priority to pilot agricultural financial services in Dazhou. The financial management department should focus on improving the financing environment and solving the problem of accessing financial services. Strengthen the construction of rural informatization, promote the "Internet + " of the rural industry, and develop digital finance and industrial chain financial services. Make full use of the Internet and big data technology to reduce transaction costs and control credit risks. 


\subsection{Strengthening the Construction of Rural Financial Infrastructure}

The financial resources possessed by the region are an important indicator to measure the availability of regional finance. Through deepening the reform of the financial system and the use of financial technology, traditional financial institutions are empowered to work from the perspectives of credit concepts, business environment, and human capital investment to improve the supply of rural financial elements, to solve the problem of regional financial imbalances. Improve the layout of agricultural financial institutions and their institutions, promote modern payment and settlement tools, and improve the service capabilities of financial institutions. Promote the supply-side reform of agriculture-related finance, further promote rural financial innovation, and build a green financial service system suitable for the development of regional agricultural industries. Strengthen bank-insurance cooperation, bank-government cooperation, actively play the role of government guarantee companies, make good use of the risk compensation fund for rural revitalization of the agricultural industry, improve the risk-sharing mechanism, and increase credit through various forms. Improve the financial support agriculture policy system, strengthen the construction of the rural credit system, and continuously improve the rural financial ecological environment.

\subsection{Optimize Financial Supervision and Assessment Methods}

"The most valuable lesson of rural reform is to respect farmers' wishes" [4]. This criterion should also be observed in financial support for the development of agricultural modernization, to avoid blindly pursuing indicators such as credit coverage rate and average household loan amount, to avoid violation of farmers' credit wishes due to assessment factors, and to pay more attention to the financial services of new agricultural business entities. Get sex. The capital of financial institutions is naturally profit-seeking, and only by insisting on market-oriented operation can the enthusiasm of financial capital be mobilized. Put pressure on commercial banks through administrative orders and performance appraisal to increase credit for agriculture, rural areas and farmers. In the case of relatively limited high-quality enterprises and projects, in order to complete the appraisal tasks, it is bound to relax credit standards and increase non-performing loans and financial risks. In the process of guiding financial support to the agricultural industry, the government must clarify the boundaries between the government and the market, and adhere to the principle that private goods are provided by private individuals and public goods are provided by the government. Agricultural infrastructure should be underpinned by fiscal funds. The government will use fiscal funds to draw water and leverage in supporting the agricultural industry, and use limited fiscal funds to leverage more financial capital and industrial and commercial capital. Improve financial supervision and conduct differentiated assessment of agricultural credit. 


\section{Conclusion}

Some agricultural industry development problems seem to be financial problems, but they cannot be solved entirely by finance. Finance is a tool that can help enterprises or industries grow bigger and stronger, but in the early stages of enterprise or industrial development, more fiscal policies and other policies are needed to help solve them. Both industry and finance have their own development rules, and we need to respect and use these rules in order to realize financial boosting industry development.

\section{Conflicts of Interest}

The author declares no conflicts of interest.

\section{References}

[1] Dazhou Agriculture and Rural Bureau (2021) Dazhou Agriculture and Rural Bureau. The Fourteenth Five-Year Plan of Agricultural and Rural Modernization in Dazhou (Draft for Soliciting Comments).

http://nyj.dazhou.gov.cn/news-show-3452.html

[2] Chenping, K. (2018) An Analysis of the Financing Issues of the New Type of Agricultural Management. Finance and Economics, 96-98.

[3] Wei, L. (2015) Research on the Financing Dilemma and Countermeasures of the New Type of Agricultural Management. Hubei Agricultural Sciences, 54, 738-742.

[4] Xiangzhi, K. (2018) The Most Precious Experience of Rural Reform is to Respect the Wishes of Farmers. China Farmers Cooperative, 42. 